\title{
EFEKTIFITAS LAYANAN PENGUASAAN KONTEN DENGAN TEKNIK SELF MANAGEMENT UNTUK MEREDUKSI PERILAKU AGRESIF SISWA KELAS VIIISMP NEGERI 12 KOTA BENGKULU
}

\author{
Nur Latifa, I.Wayan Dharmayana, Vira Afriyati \\ Prodi Bimbingan dan Konseling Fakultas Keguruan dan Ilmu Pendidikan \\ Universitas Bengkulu \\ nurlatifa2110@gmail.com, iwayand386@gmail.com, vira@konselor.org
}

\begin{abstract}
ABSTRAK
Penelitian ini bertujuan untuk mendeskripsikan pengaruh layanan penguasaan konten dengan teknik self managemen terhadap perilaku agresif siswa kelas VIII di SMP Negeri 12 Kota Bengkulu. Penelitian ini merupakan penelitian kuasi eksperimen dengan desain penelitian one grup pretest dan posttest. Sampel pada penelitian ini adalah siswa kelas VIII H SMP Negeri 12 Kota Bengkulu. Hasil penelitian menunjukan adanya penurunan perilaku agresif siswa setelah diberikannya layanan penguasaan konten dengan teknik self management. Hal ini dapat terlihat dari hasil pengujian hipotesis dengan nilai uji $\mathrm{t}=12,629$, nilai sig sebesar $0,000(\mathrm{p}<0,005)$. Artinya ada pengaruh layanan penguasaan konten dengan teknik self managementterhadap perilaku agresif siswa.
\end{abstract}

Kata kunci : layanan penguasaan konten, teknik self management, perilaku agresif

\section{THE EFFECTIVENESS OF CONTENT MASTERY SERVICES USING SELF MANAGEMENT TECHNIQUE TO REDUCE STUDENTS' AGRESSIVE BEHAVIOR GRADE EIGHTH OF SMPN 12 BENGKULU}

\begin{abstract}
This study aimed to describe the influence of content mastery services using self management technique toward the students'aggressive behavior at grade eighthSMPN 12 Bengkulu. This research was a quasi-experimental study with one group pretest and posttest research design. The sample in this study was class VIII H SMPN12 Bengkulu. The results showed a decrease in the students'aggressive behaviorafter the content mastery services using self management technique. This could be seen from the results of testing the hypothesis with $t$ test value $t=12.629$, the sig value of 0.000 ( $\mathrm{p}<0.005)$. It means that there was the influence of content control services using self management technique on students' aggressive behavior.
\end{abstract}

Keywords:content mastery services, self management technique, aggressive behavior 


\section{Latifa,Dharmayana, Afriyati}

\section{Pendahuluan}

Remaja adalah fase yang sangat penting pada kehidupan manusia, karena merupakan masa peralihan dari masa kanak-kanak ke masa dewasa (Firdaus; 2012:23). Pada fase ini remaja akan mengalami banyak perubahan-perubahan mulai dari perubahan fisik, kognitif, dan sosialemosional. Masa remaja sering dikatakan sebagai priode "badai dan tekanan" yaitu sebagai suatu masa dimana terjadi ketegangan emosi yang tinggi yang diakibatkan adanya perubahan fisik dan kelenjarAnnisavitry (2017:1). Menurut Nisfianoor (2005;89)Perubahan fisik dapat menimbulkan masalah-masalah pada diri remaja tersebut yang biasa disebut sebagai masa krisis. Masa krisis yang kerab dialami remaja adalah kebimbangan identitas diri, jika remaja tidak berhasil dalam menentukan identitas diri yang tepat maka kebimbangan tersebut dapat menyebabkan perilaku menyimpang.

Menurut hasil penelitian Yustisi (2013:21) hasil menunjukkan bahwa sekitar 30\% dari siswa di sekolah berperilaku agresif. Anak-anak kelas kecil (kelas 1-3) lebih sering menampakkan agresivitasnya melalui perilaku fisik, sedangkan untuk anak-anak yang berada dikelas besar (kelas 4-6) lebih sering memunculkan agresivitas verbal.

Permasalahan yang ditemukan di lapangan adalah terdapat beberapa siswa di SMP Negeri 12 Kota Bengkulu yang secara sengaja berperilaku agresif,seperti memukul mencubit temannya, berkata kasar, menghina, danmengejek serta merusak benda milik sekolah dan milik temantemannya. Sehingga menyebabkan sakit fisik seperti memar dan luka bagi yang mendapatkan perlakuan fisik dan sakit hati bagi siswa yang dihina serta rusaknya benda milik sekolah dan milik teman-temannya. Perilaku agresif ini tidak hanya dilakukan siswa terhadap temantemannya saja, namunjuga terhadap guru seperti melawan dan mencemooh guru ketika belajar. Hal ini mengakibatkan siswa yang berperilaku agresif dijauhi oleh teman-temannya dan membuat guru tidak senang dengan siswa tersebut.

Banyaknya kasus agresivitas yang dilakukan anak-anak yang membuat para guru kewalahan dalam menghadapi siswa di sekolah.Berbeda dengan hal tersebut peneliti ingin mencoba mereduksi perilaku agresif anak dengan menggunakan teknik self management. Peneliti tertarik untuk melakukan penelitian dengan judul "Efektifitas Layanan Penguasaan Konten dengan Teknik Self Management untuk mereduksi perilaku agresif anak kelas VIII SMP Negeri 12 Kota Bengkulu".

\section{Metode Penelitian}


Metode yang digunakan pada penelitian ini adalah kuasi-eksperimen.. Penelitian kuasieksperimen gagasan yang mana dalam pelaksanaannya melakukan penugasan random. Metode yang digunakan adalah metode kuantitatif one-grup pre-test dan post-test desing digunakan untuk mengetahui ketepatan layanan penguasaan konten teknik self management terhadap perilaku agresif siswa ..... Populasi pada penelitian ini adalah siswa siswi kelas VIII SMP Negeri 12 Kota Bengkulu dan subjek pada penelitian ini adalah siswa kelas VIII H SMP Negeri 12 Kota Bengkulu. Pengambilan subjek penelitian ini dengan menggunakan purposive sampling Dalam penelitian ini digunakan metode pengumpulan data dengan Kuesioner (Skala Psikologi ) dan Dokumentasi.

Uji Validitas instrument merupakan prosedur pengujian untuk melihat apakah pernyataan yang digunakan dalam skala agresif dapat mengukur dengan cermat atau tidak menggunkan bantuan SPSS 16. Uji Validitas ini menggunakan rumus product moment (Winarni, 2011:193). Hasil Realibilitas instrument dalam penelitian ini menggunakan rumus Alpha Croanbach's dengan bantuan aplikasi komputer Statistical Packages for Sosial Sience (SPSS) versi 16 for windows.

Teknik analisis data yang digunakan pada penelitian ini adalah bersifat kuantitatif yaitu model statistik. Analisis data dalam riset kuantitatif bertujuan menguji hipotesis statistik, dalam pengujian hipotesis terdapat kekeliruan, baik dalam menerima hipotesis yang seharusnya ditolak ataupun dalam hipotesis yang seharusnya diterima Mohammad (2014:296).

\section{Hasil dan Pembahasan}

Deskripsi data yang disajikan dalam penelitian ini adalah deskripsi tingkat perilaku agresif sebelum, sesudah layanan penguasaan konten dengan teknik self management mereduksi perilaku agresif. Perilaku agresif adalah tingkah laku yang diharapkan untuk melukai orang lain, perilaku yang dimaksud untuk melukai orang lain (baik secara fisik maupun verbal) atau merusak harta benda Kulsum (2014:242). Teori tersebut diperkuat oleh Yunika (2013:216), yang menyatakan perilaku agresif adalah bentuk perilaku yang dimaksudkan untuk menyakiti atau melukai makhluk hiduplain baik secara fisik maupun verbal. Deskripsi tingkat perilaku agresif sebelum diukur dengan 58 responden terdiri dari 50 item dengan skala Likert yang bergerak dari 1-5. Sehingga diperoleh 31 item soal valid dengan rentang minimum 31 x $1=31$, rentang maksimum 31 x $5=177$, sehingga luas jarak sebarannya adalah $177-31=124$. Dengan 
demikian setiap satuan standar deviasi brnilai $\sigma=23,25$ dan meannya adalah 77,5. Pemberian pre-test jumlah responden 28 orang siswa diperoleh hasil:

Tabel 1

Sebelum Treatment Perilaku Agresif

\begin{tabular}{cccc}
\hline Interval & Frekuensi & Presentase & Katagori \\
\hline$>112$ & 25 & $89 \%$ & Sangat tinggi \\
\hline $89-111$ & 1 & $4 \%$ & Tinggi \\
\hline $76-88$ & 2 & $7 \%$ & Sedang \\
\hline $67-87$ & 0 & $0 \%$ & Rendah \\
\hline$<66$ & 0 & $0 \%$ & Sangat rendah \\
\hline Total & 28 & & \\
\hline
\end{tabular}

Berdasarkan Tabel 1 dapat dilihat siswa kelas VIII H SMP Negeri 12 Kota Bengkulu memiliki persentase $89 \%$ dengan katagori sangat tinggi berjumlah 25 orang, $4 \%$ dengan kategori tinggi berjumlah 1 orang dan 7\% dengan kategori sedang dengan jumlah 1 orang. Hasil pre-test menunjukkan tingginya perilaku agresif siswa sebelum diberikan layanan penguasaan konten dengan teknik self management. Hasil dari pengujian Reliabelitas pada skala agresif didapati nilai Croanbach's, Alpha

Tabel 2

Hasil Uji Reliabelitas

Untuk Perilaku Agresif

\begin{tabular}{|c|c|c|}
\hline Cronbach's Alpha & $\begin{array}{c}\text { Cronbach's Alpha } \\
\text { Based on Standardized } \\
\text { Items }\end{array}$ & $\begin{array}{l}\text { No of } \\
\text { Items }\end{array}$ \\
\hline .978 & .974 & 31 \\
\hline
\end{tabular}

Berdasarkan Tabel 2 didapati alpha cronbacth senilai 0,978 yang artinya lebih besar dari 0,8 maka artinya hasil tersebut dapat dikatakan reliabel dengan nilai yang baik. Setelah pengujian dilakukan peneliti memberikantreatment selama $6 \mathrm{kali}$, dengan treatment yang diberikan adalah layanan penguasaan konten dengan teknik self management. Layanan penguasaan konten adalah layanan bantuan kepada individu (sendiri-sendiri ataupun dalam kelompok) untuk menguasai kemampuan atau kompetensi tertentu melalui kegiatan belajar. 
Layanan penguasaan konten tersebut membantu individu menguasai aspek-aspek konten yang didalamnya terkandung fakta, data, konsep, proses hukum dan aturan, nilai, persepsi afeksi, sikap, dan tindakan yang terkait didalamnya secara tersinergikan. Dengan penguasaan konten individu diharapkan mampu memenuhi kebutuhannya sendiri mengatasi masalah-masalah yang dialaminya (Prayitno, 2017:94). Layanan yang diberikan dengan teknik self management, pengelolaan diri adalah suatu strategi pengubahan perilaku yang dalam prosesnya konseli mengarahkan perubahan perilakunya sendiri dengan suatu teknik atau kombinasi teknik teurapetik (Sholihah, 2006: 519). Self-management adalah menunjuk pada suatu teknik dalam terapi kognitif behavioral berlandaskan pada teori belajar yang dirancang untuk membantu para klien mengontrol dan mengubah tingkah lakunya sendiri ke arah tingkah laku yang lebih efektif, sering dipadukan dengan ganjaran diri (self-reward) (Sholihah (2006:297)). Kegiatan layanan yang dilakukan sebanyak 6 pertemuan pada siswa kelas VIII H SMP Negeri 12 Kota Bengkulu dengan jadwal kegiatan:

Tabel 3

Pelaksanaan Treatment Layanan Penguasaan Konten dengan teknik Self Management.

\begin{tabular}{ll}
\hline \multicolumn{1}{c}{$\begin{array}{c}\text { Tanggal } \\
\text { Pelaksanaan }\end{array}$} & \multicolumn{1}{c}{ Materi } \\
\hline 29 April 2019 & $\begin{array}{l}\text { Penyimpangan pada Remaja dan Strategi Self } \\
\text { Monitoring }\end{array}$ \\
\hline 3 Mei 2019 & $\begin{array}{l}\text { Pencegahan Penyimpangan pada Remaja dan } \\
\text { Strategi Self Control }\end{array}$ \\
\hline 7 Mei 2019 & Kekuatan pikiran dan Strategi Self Efficacy \\
\hline 11 Mei 2019 & Mengelola Perasaan dan Strategi Self Efficacy \\
\hline 13 Mei 2019 & Self Management \\
\hline 20 Mei 2019 & Evaluasi hasil pelatihan \\
\hline
\end{tabular}

Pertemuan pertama pada tanggal 29 April 2019 dengan materi "Penyimpangan pada Remaja dan Strategi Self Monitoring", siswa masih belum kondusif dengan masih adanya siswa yang berteriak didalam kelas, menggangu teman, mendorong dan mengejek temannya, namun kejujuran siswa untuk mengakui perilaku buruknya menunjukan niat siswa untuk berubah kearah yang lebih baik. 


\section{Latifa,Dharmayana, Afriyati}

Tanggal 3 Mei 2019 pertemuan kedua dengan materi "Pencegahan Penyimpangan pada Remaja dan Strategi Self Control," perubahan perilaku siswa yang membaik dengan cara siswa mengikuti kegiatan dengan antusias dan terjadi penurunan tingkat perilaku agreif siswa berteriak dikelas dengan pelatihan self control yang mana perlakuan peneliti ke siswa dengan pemberian wadah penyaluran energy di dalam diri siswa.

Pada pertemuan ketiga tanggal 7 Mei 2019 peneliti menyampaikan materi "Kekuatan Pikiran dengan strategi Self Efficacy" dengan pelatihan kekuatan pikiran yang diberikan siswa menunjukkan penurunan agresifnya dengan tidak lagi berfikir buruk terhadap temannya sehingga perilaku buruk menggosip sedikit berkurang.

Pada pertemuan keempat dengan materi "Mengelola Perasaan dan Strategi Self Efficacy", pada tanggal 11 Mei 2019 tampak siswa mengikuti kegiatan pelatihan dengan antusias dan bersemangat, penurunan perilaku agresif tampak dari siswa yang tertib dalam mengikuti pelatihan. Tanggal 13 Mei 2019 di pertemuan kelima peneliti memberikan treatment Self Management dengan memberikan lembar tugas kepada siswa, lembar tugas diberikan guna pengaplikasian strategi-strategi self management dalam kurun waktu 1 minggu, dan hasil dari kegiatan siswa akan dievaluasi bersama pada tanggal 20 Mei 2019, sebagai berikut :

Tabel 4

Perilaku agresif dan cara penanganannya

\begin{tabular}{ccc}
\hline Perilaku Agresif & Penanganan & Frekuensi \\
\hline Menjahili teman & Self management & 5 \\
\hline Berkata kasar & Self control & 8 \\
\hline Berbohong & Self monitoring & 4 \\
\hline Berkelahi & Self control & 4 \\
\hline Membolos & Self management & 2 \\
\hline Mengosip & Self management & 5 \\
\hline & & 28 \\
\hline
\end{tabular}

Pengukuran perilaku agresif setelah pemberian treatment dengan layanan penguasaan konten teknik self management dilakukan dengan pemberian post-test kepada siswa yang dilaksanakan pada tanggal 23 Mei 2019 yang mendapatkan hasil : 


\section{Tabel 5}

Distribusi Frekuensi Skor Perilaku Agresif

\begin{tabular}{ccc}
\hline Interval & Frekuensi & Katagori \\
\hline$>112$ & 0 & Sangat tinggi \\
\hline $89-111$ & 9 & Tinggi \\
\hline $76-88$ & 12 & Sedang \\
\hline $67-87$ & 6 & Rendah \\
\hline$<66$ & 1 & Sangat rendah \\
\hline Total & 28 & \\
\hline
\end{tabular}

Berdasarkan Tabel 5 tampak penurunan perilaku agresif dari sangat tinggi ke tinggi, sedang, rendah dan sangat rendah.

\section{Gambar 1}

\section{Grafik Penurunan Skor dari Perilaku Agresif}

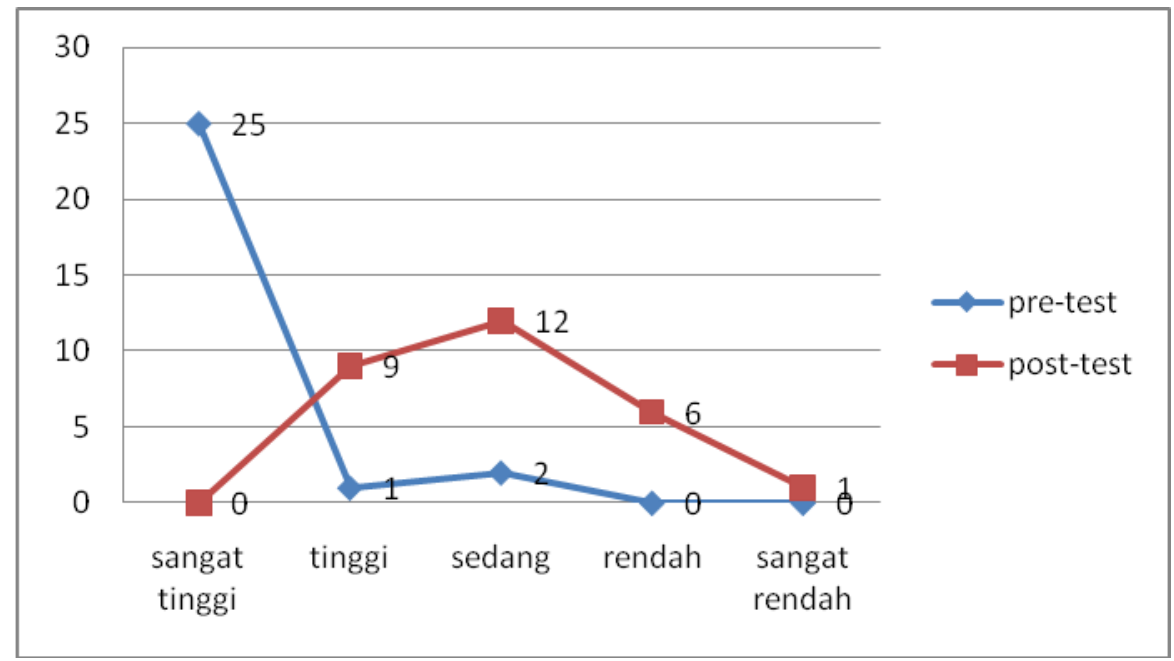

Gambar 1 menunjukan penurunan skor yang signifikan dari perilaku agresif siswa sebelum diberikan layanan penguasaan konten dengan teknik self management dengan sebelum diberikan layanan. Uji hipotesis dengan uji t seperti pada Tabel 6.

Tabel 6

Uji Beda Perilaku Agresif Sebelum dan Sesudah Treatment dengan Uji t

t Sig. (1-tailed) 


\begin{tabular}{lll}
\hline pre - post $\quad 12.459 \quad .000$ \\
\hline
\end{tabular}

Pada Tabel 6, dapat dilihat dari uji t sebesar 12,459 ( $\mathrm{p}<0,005)$, Hal ini membuktikan bahwa ada perbedaan tingkat agresif siswa setelah diberikan layanan penguasaan konten dengan teknik self managementdi bandingkan sebelum diberikan treatment.

Hasil penelitian ini, selaras dengan penelitian Monica, Ruslan Abdul Gani (2016) yang menunjukkan bahwa terdapat perkembangan tanggung jawab peserta didik setelah mendapatkan layanan konseling behavioral dengan teknik self management. Perubahan perilaku siswa kearah baik yang diberi layanan Bimbingan dan Konseling dengan teknik self management juga terkonfirmasi dengan penelitian yang dilakukan oleh Ayu Dhya dan Hadi Warsito (2013) ; Alamri (2015) ; Sididiqah (2010) tentang self management untuk mereduksi perilaku agresif, mengelola amarah, perilaku terlambat dan perilaku kenakalan remaja yang mengalami perubahan hal tersebut sesuai dengan siswa kelas VIII H di SMP Negeri 12 Kota Bengkulu yang mengalami perubahan melalui pelatihan self management, pada siswa disebabkan oleh siswa secara mandiri mampu berkomitmen menerapkan self management. Self management memberikan siswa rasa tanggung jawab untuk berkomitmen dalam menyelesaikan perilaku yang menggangu dalam kehidupannya.

\section{Kesimpulan}

Perilaku agresif siswa kelas VIII H SMP Negeri 12 Kota Bengkulu sebelum diberikan layanan penguasaan konten dengan teknik self management masih tergolong sangat tinggi, dilihat dari hasil pre-test siswa sebelum diberikan treatment layanan penguasaan konten dengan teknik self management.Perilaku agresif siswa kelas VIII H SMP Negeri 12 Kota Bengkulu setelah diberikan layanan penguasaan konten dengan teknik self management mengalami penurunan. Hal ini ditujukkan dengan adanya penurunan skor yakni, penurunan perilaku agresif setelah diberikannya layanan pnguasaan konten dengan teknik self management yang dapat dilihat dari hasil post-test siswa. Ada pengaruh layanan peguasaan konten dengan teknik self management terhadap penurunan perilaku agresif siswa kelas VIII H SMP Negeri 12 Kota Bengkulu. Terjadi perubahan perilaku agresif yang signifikan, dapat dilihat dari perbandingan hasil pre-test dan post-test siswa. Dengan demikian dapat disimpulkan bahwa dengan pemberian 
layanan penguasaan konten dengan teknik self management dapat mereduksi perilaku agresif siswa.

\section{Daftar Pustaka}

Alamri, Nurdjana. (2015). Layanan Bimbingan Kelompok Dengan TeknikSelf Management Untuk Mengurangi Perilaku Terlambat Masuk Sekolah (studi pada siswa kelas X SMA 1 Gebong Tahun 2014/2015). Jurnal Konseling GUSJIGAN Vol 1 No. 1 Tahun 2015 ISSN 2460-118.

Annisavitry, Yadinda, (2017). Hubungan Antara Kematangan Dengan Agresivitas Pada Remaja. Character: Jurnal Psikologi Pendidikan Volume 04 Nomor 1 Tahun 2017

Dyah Ayu, Hadi Warsito. (2013). Penerapan Strategi Pengelolaan Diri (Self Management) untuk Mengurangi Kenakalan Remaja Korban Broken Home.

Kulsum, Umi, dan Mohammad Jauhar, (2014). "Pengantar Psikologi Sosial". Jakarta : Prestasi Pustaka Jaya.

Mohammad, Ali. (2014). Metodelogi \& Aplikasi Riset Pendidikan. Jakatra: PT Bumi Aksara.

Prayitno. (2017). Konselor Profesional yang berhasil.Jakarta:PT RajaGrafindo Persada.

Sholihah, Nikmatus. (2013). Penerapan Self Management untuk meningkatkan disiplin. Jurnal BK UNESA, Vol 03 Tahun 32013.

Siddiqah, Laela. ( 2010 ). Pencegahan dan Penanganan Perilaku Agresif Remaja Melalui Pengelolaan Amarah. Jurnal Psikologi Volume 37, No.1, Juni 2010: 50-64.

Yunika, Septiana. (2013). Kegunaan Konseling Kelompok Realita Untuk Menurunkan Perilaku Agresif Siswa di SMP PGRI 1 Karang Empat Surabaya.Jurnal BK UNESA. Volume 03 Nomor 01 Tahun 2013, $217-222$

Yustisi, MS. (2013). Pelatihan Regulasi Emosi untuk Menurunkan Perilaku Agresif pada Anak. Humanitas. Vol x no. 1 Januari 2013. 